\title{
Beauty Myth in Novels by Tiwiek S.A
}

\author{
Yunita Ernawati \\ Universitas Negeri Surabaya \\ Surabaya, Indonesia \\ yunitaernawati@unesa.ac.id
}

\author{
Bambang Purnomo \\ Universitas Negeri Surabaya \\ Surabaya, Indonesia \\ bambangpurnomo@unesa.ac.id
}

\begin{abstract}
This research is motivated by the issue of women that is reproduced and revised continuously up to this day. This thing can be seen is seen in literary works. In this case, the author of Javanese literature, namely Tiwiek S.A, also consistently discussed the issue of women in each of her literary works. One of the issue of women in her work is the concept construction of Javanese women's beauty. Women's beauty is always constructed with an ideal body shape where the ideals have been formed by the community for a long time. Therefore, it makes women depressed with the fetter of beauty concept. This research tries to dismantle how the concept of beauty is constructed in novels by Tiwiek S.A and to find out if there any importance behind the presence of beauty myths in novels by Tiwiek S.A. In order to answer that problem, Naomi Wolf's Beauty Myth Theory which is then supported by the theory of gender feminism is used as a knife for analysis in this study.
\end{abstract}

Keywords-component, beauty myths, gender, feminism, Javanese novels, Tiwiek S.A

\section{INTRODUCTION}

Talking about Javanese women is not only about all women who speak Javanese as mother language, nor also about all women who live in Java as Javanese who have Javanese parents. However, if we discuss about Javanese women, then we also discuss about strong individuality through the types of Javanese women that are polite, refined and friendly. It is no exaggeration that Javanese women are labeled with a friendly, patient and refined nature. This is seen based on Javanese culture which is identical with smooth words, composed, calm, strong self-control to maintain harmony by upholding family values. Soft character and strong self-control of Javanese women are not only seen from the words but also the style of dress.

Learning the character of Javanese society through Javanese culture cannot be separated from its patriarchal concept. From the view of feminism, the concept of patriarchy is too subordinating Javanese women. The dichotomy between men and women in a patriarchal ideology increasingly obscures women with all their roles and actions. As we have known, patriarchal ideology places women only in the domestic sector. The emergence of women's awareness of the needs of their existence can finally place them in the public sector. However, this does not necessarily make women obscure their label as the main role holder in the domestic sector which has already been given to them.

Social construction labels domestic sector to women based on their natures that are motherhood, caring, obedient, loving, and so on. The natures used as the basis for the placement of women in the domestic sector still seem to cause problems for women. When viewed in the concept of Javanese women who have docile souls and polite nature.

Nowadays Javanese women are also euphoric about the success of the feminist movement which has led them to shift to the public sector. Women's freedom from feminine mysticism about domesticity in literary works began to be felt with the birth of works that present women who have professional abilities. Women who have been free from feminine mysticism and have begun to engage in various professions in these literary works, especially in literary works written by male authors, in one way or another, is not really as free as they had hoped. One of the things that makes these women do not really feel free is because they have to obey the concepts related to their beauty image.

Naomi Wolf [1] says that works produced in masculine culture create beauty myths that weaken the advancement of women. The works written by men teach women that the most beautiful women in the world are men's creations. Women learn that stories happen to "beautiful" women, and stories do not happen to women who are "not beautiful", so they try to adhere to the concept of ideal beauty. Women's obedience to ideal beauty concepts returns women to the shackles of femininity and literary works have recreated that reality [2] [3]. One of the literary works that created this reality was novels by Tiwiek S.A.

Tiwiek S.A or Suwignyo Adi, born on June 8th, 1948 in Tulungagung, actively writes educational articles as well as producing literary works in the form of short story, serial story, and novels. In each of her work, Tiwiek S.A always presents a depiction of Javanese women. Tiwiek S.A illustrates how women try to fill the community's definition of "perfect beauty" that will not be possible. Thus, how does Tiwiek S.A describe the concept of beauty that is presented in his novel? This question arises from male writers. Why beauty is considered important to be presented in Tiwiek S.A's work? What is the correlation between the concepts of Javanese female beauty described by Tiwiek S.A with the myth of Wolfian beauty? In order to get answers from questions that arise based on the problem of the beauty myth in the novel Tiwiek S.A, researchers feel the beauty myth theory Naomi Wolf is appropriate to use. 


\section{METHODS}

\section{A. Design}

This study uses the beauty myth theory Naomi Wolf format. This study uses the Beauty Myth theory by Naomi Wolf. Beauty myths are used to understand and examine aspects that are considered related to the concepts of beauty that curb women in the form of "beauty images" of women. According to Naomi Wolf [1], the myth of beauty actually always refers to behavior (inner beauty) and appearance (outer beauty). Outer beauty involves physical, such as face, hair, while inner beauty can be interpreted as intangible power (strength that is not physically visible). Inner beauty is not an innate beauty that a person has from birth, but is a process of personality learning obtained from a long process. These two beauty characters are the references for women to get the title as "beautiful women".

\section{B. Data}

This research uses novels by Tiwiek S.A as data. In this research, the novels are limited to the following; Srepeg Tlutur, Guwa Banger, Pinatri Ing Teleng Ati, and Sumi.

\section{Data Collection}

Acording to Sugiyono [4] method of data collection means a set of ways or techniques to obtain empirical facts related to literary research problems. Data collection in this study was conducted in the form of primary and secondary data collection. Primary data is data taken from texts in novels by Tiwiek S.A. While secondary data is data taken from a number of references, namely books, journals, or other studies related to the object of study. Collecting data by means of a literature study is the collection of data related to the research problem collected by the researcher.

\section{D.Data Analysis}

According to Sugiono [4] method of data analysis is a set of ways or techniques to draw the relation between one data and another data which leads to a scientific knowledge. The analysis in this study uses descriptive qualitative analysis.

\section{RESULTS AND DISCUSSION}

\section{A. Construction of Beauty Concepts in Novels by Tiwiek S.A}

Issues regarding women have always been reduced in every discussion. In many issues, women are associated with beautiful and not beautiful. Beauty is constructed as a concept inherent in women. In addition, the concept can change from time to time. The concept of beauty can be detrimental or can be beneficial for women. Beauty is always associated with contestation, capitalistic industry and institutions called It can also be a tool that reinforces male dominance. Hence, the real beauty is not solely about women, but rather a matter of male institutions and power. Beauty is an expression of power relations created by men in an effort to spark the fire of women's resistance in accordance with physical standards [1]. This is also reflected in the works of Tiwiek S.A.
As the author of Javanese novels, Tiwiek often presents women in the public sphere. The women in Tiwiek's works are depicted with charming beauty. The beauty of the charming woman is more emphasized on body shape.

"Marlupi, anak wuragile Pak Manaf iku pancen ayu. Pakulitane kuning. Pawakane weweg. Rambute ngandhanandhan. Mripate blalak-blalak”. (Tiwiek, 2016:156/SP).

"Marlupi, anak bungsu Pak Manaf itu memang cantik. Kulitnya kuning, badannya montok. Rambutnya indah. Matanya indah". (Tiwiek, 2016:156/SP).

("Marlupi, Mr. Manaf's youngest daughter is indeed beautiful. Her complexion is olive yellow, her body is curvaceous. Her hair is beautiful. Her eyes are beautiful ". (Tiwiek, 2016: 156/ SP).)

In the novel Srepeg Tlutur, it is seen that people construct beauty through skin color, body shape, hair, and eye types. Olive yellow skin color can make Javanese women beautiful. Beautiful big eye shapes are also categorized as female beauty. The physical form used as an indicator in labeling "beautiful" women is also seen in Tiwiek S.A's other works, as follows;

"Praupane kang bunder tur ayu, kulite kang mrusuh resik, rambute kang dipotong cendhak mamerake gulune kang apik. Lan sing paling ora nguwati ... dhadhane! (Tiwiek, 2013:31$32 / G B)$

"aku berani memberi nilai sembilan! Memang sempurna (menurut ukuranku). Wajahnya yang bulat dan cantik, kulitnya kuning langsat bersih, rambutnya dipotong pendek memprlihatkan lehernya yang bagus. Dan yang paling tidak tahan... dadanya! (Tiwiek, 2013:31-32/GB).

"I dare give a score of nine! It is perfect (according to my measurements). Her face is round and beautiful, her skin is very clean yellow, and her hair is cut short showing her nice neck. And the least bearable ... her chest! (Tiwiek, 2013: 31-32 / GB).

In Guwa Banger novel, it can also be seen the physical depiction of women as indicators of the woman said to be beautiful. Olive yellow skin, short hair and beautiful breasts as a benchmark for women said to be beautiful. Likewise with another Tiwiek S.A novel entitled Sumi. In the novel, it is depicted that beautiful Javanese women are women with olive yellow skin and have large breasts. This is seen in the following quote:

"Mripate pencilakan nalika nyawang dhadhane Sumi kang kuning mrusuh. Dhadha sing wiwit katon mentheg". (Tiwiek, 2017:3/ S)

"Matanya jelalatan ketika melihat dadanya Sumi yang kuning langsat. Dada yang sedari tadi terlihat berisi" (Tiwiek, 2017:3/ S)

"His eyes were so miserable when he saw Sumi's chest was olive yellow. The chest that looks plump"(Tiwiek, 2017: 3 / S)

The depiction of a plump chest is one indicator where women will be seen as beautiful and can steal the attention of many men. This female figure named Sumi is described as a figure of a young village woman. At a young age, Sumi looked 
beautiful even though she was born from a poor family. Her beauty radiates even more when Sumi's skin looks clean and her breasts begin to become denser. The skin of Javanese women with fair skin as an indicator of women can be said to be pretty in the novels by Tiwiek S. A. can also be seen in the novel Pinatri Ing Telenging Ati with quotes as follows;

“...weton ndesa nanging ayu. Kulite resik..” (Tiwiek: 2014:9/PITA).

"...asal dari desa tapi cantik. Kulitnya bersih.." (Tiwiek: 2014:9/PITA).

"... from the village but beautiful. Her skin is clean... "(Tiwiek: 2014: 9 / PITA).

In the novel Pinatri Ing Telenging Ati, the depiction of beautiful women is young and clean-skinned. Tiwiek also added that both women from the village and from the city, if they have clean skin, they are beautiful. This adds to the array of indicators for women to be beautiful.

Through the description above, all of Tiwiek's novels which are the object of study in this study have indicators of body shape, skin color, eye shape, hair type and others. Therefore, it can be said that it is still under discussion that the beauty of women is seen in outer beauty. In this case, women are said to be beautiful just by looking at them from the outside

The indicators actually become beauty myths that harm Javanese women. That is because the majority of brownskinned mature become shackled with beautiful and not beautiful sentences. Thus, many of the women become burdened with the concept of beauty reconstructed in the community.

\section{B. The Image of Beautiful Face of Javanese Women in Novels by Tiwiek S.A}

Women are always attached to beauty and prettiness. Through the social system, beauty is one of the feminine traits. In addition, it is also created through culture. The attachment that women have beauty and prettiness actually pushes women to a belief in beauty myths that are already created. Women actually fall for a benchmark that women must be beautiful.

An ideology that makes women feel "worthless" is needed to match the way pioneered by feminism so that women feel more valuable. This makes the social order feel the need to defend them by avoiding facts about real women, their faces, bodies and voices, and reduces the meaning of womanhood to become a fixed and continuously reproduced beauty image [1].

Beauty myths teach women that they have little control and few choices. The image of women in beauty myths is reductive and stereotyped. Naomi Wolf [1] argues that on some occasions, there are limits on the number of faces that are considered "beautiful" faces. Through such limited perceptions of women, women have become accustomed to seeing their choices as limited.

In novels by Tiwiek S.A., beautiful village women are depicted with ideal beauty as what the community has constructed. Not only that, they also have inner beauty that has also been acknowledged by the public although all of them are poor rural women. However, that is what causes them to be pushed to enter the public sphere.

Through their abilities, they try to work to meet their needs. Nevertheless, without them realizing the beauty that is in them has a plus in paving their way to the public sphere. The thing that is the most easily be seen is when beautiful female characters are given more attention in society than nonbeautiful women.

This female figure in the four novels by Tiwiek S.A has inner beauty. Therefore, they gain much sympathy in general and men in particular. As in the following excerpt from the novel Srepeg Tlutur;

"Bocahe ayu, trapsila, sekolahe ya ora endhek nemennemen”. (Tiwiek, 2016:63/SP).

“Anaknya cantik, sopan santun, sekolahnya juga gak pendekpendek juga”. (Tiwiek, 2016:63/SP).

"The child is beautiful, good manners; the school is also not short too". (Tiwiek, 2016: 63 / SP).

The quotation above shows that the beauty of female characters in the novel Srepeg Tlurur is followed by inner beauty that appears through courtesy and education. Hence, many men fall in love even the people also sympathize. The image of women is built by combining inner beauty and outer beauty.

\section{The importance behind The Concept of Beauty in Novels by Tiwiek S.A}

Beauty has been formed for a long time by a society where men dominate in this matter. Women interpret this thing very diversely. However, in novels by Tiwiek S.A., women are depicted as innocent looking unaware of the interests of men in their beautiful labeling. Talking about beauty, it is not just about women with body shapes that have been created so beautifully. It is more to the role of men with their power. Beauty is an expression of power relations created by men in an effort to spark the fire of women's resistance in accordance with physical standards [1]. Likewise, it is described by Tiwiek S. A. through these novels.

In the four novels of Tiwiek that were used as the object of study in this study, all showed that only women who could meet the criteria of beauty received the attention of the surrounding community, especially men. The beauty that is in women actually causes desire.

"Priyayi kakung setengah yuswa iku sansaya nyakel. Malah astane banjur ngranggeh pundhake Munarsih kang ngliga kuning mrusuh "(Tiwiek, 2016:21/SP)

"Laki-laki paruh baya itu semakin nakal. Malah tangannya meraba pundak Munarsih yang terlihat berkulit kuning langsat". (Tiwiek, 2016:21/SP)

"Middle-aged men are getting naughtier. In fact, his hand touched Munarsih's shoulder, which was seen with fair skin. (Tiwiek, 2016: 21 / SP) 
In the novel Srepeg Tlutur (SG), it is seen that the depiction of the figure of a woman with olive yellow skin and beautiful face like the character of Muntarsih actually experienced sexual harassment. Muntarsih was sexually abused by a middle-aged man who was his mother's employer. It is described that the man praised the beauty of Muntarsih while touching the body of muntarsih which in the end rape occurred. In addition, there are also other novels such as the following;

"Aku wani mbiji sanga! Teneh sampurna tenan (manut ukuranku). Praupane kang bunder tur ayu, kulite kang mrusuh resik, rambute kang dipotong cendhak mamerake gulune kang apik. Lan sing paling ora nguwati ... dhadhane! Dhadha kang rinengga gumuk sakembaran iku mamerake kaendahan kang luar biasa (manut ukuranku lho!)". (Tiwiek, 2013:31-32/GB).

"aku berani memberi nilai sembilan! Memang sempurna (menurut ukuranku). Wajahnya yang bulat dan cantik, kulitnya kunig langsat bersih, rambutnya dipotong pendek memprlihatkan lehernya yang bagus. Dan yang paling tidak tahan... dadanya! Dadanya bagaikan gunung kembar dengan segala keindahannya yang luar biasa". (Tiwiek, 2013:3132/GB).

"I dare give a score of nine! It is perfect (according to my measurements). Her face is round and beautiful, her skin is very clean yellow, and her hair is cut short showing her nice neck. And the least bearable ... her chests! Her chests are like a twin mountains with all its extraordinary beauty ". (Tiwiek, 2013: 31-32 / GB)

The novel Guwa Banger (GB) shows the beauty of women that actually presents verbal sexual abuse. Women are made bets and even media of jokes and harassment. But the women in the novels by Tiwiek do not realize that the labeling of beautiful women pinned on her actually leads them to bad experiences that are traumatic.

Naomi Wolf [1] says that ideal beauty is considered ideal only if it never existed. The action to realize the ideal lies in the gap between desire and satisfaction. Women are not beautiful figures without distance. This space, in the consumer society, is a profitable space. The strength of the beauty myth lies in its inherently baseless nature.

In line with this, the favorable space between women and beauty is controlled by men. This male figure is basically the main character in determining the "pretty" standard for every woman. In the case in Tiwiek's novels, the space between women and beauty is used by men to place sexual desires on beautiful women.

\section{IV.CONCLUSION}

Novels by Tiwiek S.A in this case Srepeg tlutur, Guwa banger, Pinatri Ing Teleng Ati and Sumi, represent the gender issue that is defined, by Naomi Wolf, as a beauty myth. These novels have a standard about the beautiful concept of olive yellow skin, big eyes, long black hair, long neck, big breasts and slim. Besides, all the beautiful female characters in all these novels have young age.

The depiction of the figure of a beautiful woman is not only through physical form, but Tiwiek portrays beauty through polite and educated nature as well. Even though, all of these female figures come from disadvantaged communities. The depiction of the beautiful figure of a woman from both inner beauty and outer beauty does not necessarily provide empty space without the presence of those who use it.

The beauty myth described in Tiwiek S.A's works is controlled by men. They have an interest in the beautiful construction of women in these novels. The interest is to make beautiful women the media for delivering inappropriate desires. Beautiful women ultimately get sexual abuse both physically and verbally. In physical form, that is like being touched on the chest, pinched and so on. Then the verbal form, like being seduced then becomes a bet for men. These acts of abuse both physical and verbal are traumatic which ultimately end up in women who are harmed and men who are advantaged.

\section{REFERENCES}

[1] N. Wolf, Mitos Kecantikan: Kala Kecantikan Menindas Perempuan, 2002. Terjemahan Alia Swastika. 2004. Yogyakarta: Penerbit Niagara.I.S. Jacobs and C.P. Bean, "Fine particles, thin films and exchange anisotropy," in Magnetism, vol. III, G.T. Rado and H. Suhl, Eds. New York: Academic, 1963, pp. 271-350, 2004.

[2] N. Setyaningrum, 2012. Perempuan Dan Keperempuanan: Analisis Posfeminisme Terhadap Celebrity Shopper Dan Confenssions Of A Shopaholic. Yogyakarta: Tesis FIB UGM, 2012.

[3] T. R. Putnam, Feminist Thought: Pengantar Paling Komprehensiif Kepada Arus Utama Pemikiran Feminist, 1998. Terjemahan Aquarini Priyatna Prabasmoro, Yogyakarta: Jalasutra, 2010.

[4] Sugiyono, Metode Penelitian Kuantitatif Kualitatif dan R\&D. Bandung, Alfabeta, 2011 